\title{
HONORÉ DE BALZAC, Splendori e miserie delle cortigiane
}

\section{Marco Stupazzoni}

\section{(2) OpenEdition \\ Journals}

\section{Edizione digitale}

URL: https://journals.openedition.org/studifrancesi/22856

DOI: $10.4000 /$ studifrancesi.22856

ISSN: 2427-5856

\section{Editore}

Rosenberg \& Sellier

\section{Edizione cartacea}

Data di pubblicazione: 1 avril 2020

Paginazione: 192

ISSN: 0039-2944

\section{Notizia bibliografica digitale}

Marco Stupazzoni, «Honoré de Balzac, Splendori e miserie delle cortigiane», Studi Francesi [Online], 190 (LXIV | I) | 2020, online dal 01 mai 2020, consultato il 03 août 2021. URL: http://

journals.openedition.org/studifrancesi/22856 ; DOI: https://doi.org/10.4000/studifrancesi.22856

Questo documento è stato generato automaticamente il 3 août 2021.

\section{(c) (†)}

Studi Francesi è distribuita con Licenza Creative Commons Attribuzione - Non commerciale - Non opere derivate 4.0 Internazionale. 


\title{
HONORÉ DE BALZAC, Splendori e miserie delle cortigiane
}

\author{
Marco Stupazzoni
}

\section{NOTIZIA}

HONORÉ DE BALZAC, Splendori e miserie delle cortigiane. Traduzione di M. Ferro, Introduzione di M. Bongiovanni Bertini, Milano, Mondadori, 2017, «Oscar classici», xxxvi-579 pp.

1 L'eterogeneità e la polifonia dei temi, dei personaggi, degli ambienti e dei linguaggi che percorrono e nutrono gli spazi e i ritmi narrativi di uno tra i romanzi più popolari, ma meno considerati dalla critica, almeno fino alla metà del Novecento, della Comédie humaine: Splendeurs et misères des courtisanes, trovano la loro realizzazione concreta e in divenire attraverso, soprattutto, il personaggio ambiguamente titanico di Vautrin. La figura proteiforme dell'ex-forzato Jacques Collin, che già nel Père Goriot sembrava primeggiare per intensità drammatica e complessità psicologica e morale sugli altri attori del romanzo, diventerà, in Splendeurs et misères, uno dei grandi miti della letteratura del XIX secolo, capace, allo stesso tempo, di trasmettere al lettore «l'impressione fortemente unitaria di una narrazione di vasto respiro» (p. vI dell'illuminante Introduzione al romanzo di Mariolina Bongiovanni Bertini). Le quattro parti che formano l'opera furono pubblicate tra il 1838 e il 1847 con titoli e suddivisioni differenti. Nella citata Introduzione di M. Bongiovanni Bertini al romanzo di Balzac (pp. v- XxxvI) - tradotto esemplarmente da Marise Ferro (prima edizione: Torino, Einaudi, 1964) - la curatrice, nel ricostruire con minuzia la genesi, alquanto tormentata, del testo, sottolinea il carattere antifeuilletonesco ("alla Sue") di Splendeurs et misères dove, all'intensità, tutt'altro che melodrammatica, dell'azione narrativa, che vede sempre al centro, come protagonista assoluto, Vautrin, si intreccia uno studio approfondito, quasi didattico, del mondo giudiziario, da un lato, e della complessità, contraddittoria e paradossale, della realtà sociale, dall'altro. Nel romanzo, la «plasticità polimorfa» (p. xxIx), cinica, spietata e, allo stesso tempo, ironica di Vautrin contribuisce 
in modo decisivo alla polifonia del testo. L'ambiguità dell'eroe determina, in altri termini, la forza trasfiguratrice della scrittura: si tratta, in fondo, della stessa ambiguità «che è prerogativa irrinunciabile della forma romanzo, modellata da vicino sulle tensioni sotterranee, i meccanismi contraddittori e le labirintiche complicazioni del reale» (p. xxx). 